\title{
Influence of heavy metals on hematologic parameters, body weight gain and organ weight in rats
}

\author{
N. Lopotych ${ }^{1}$, N. Panas ${ }^{1}$, T. Datsko1, S. Slobodian ${ }^{2 *}$ \\ ${ }^{1}$ Lviv National Agrarian University, Dublyany, Ukraine \\ ${ }^{2}$ Stepan Gzhytskyi National University of Veterinary Medicine and Biotechnologies \\ Lviv, Ukraine \\ *Corresponding author E-mail: solomiaslobodian@ukr.net
}

Received: 20.12.2019. Accepted 20.02.2020

\begin{abstract}
The aim of the study was to determine the effect of Cadmium and Lead salts on body weight gain and rat body weights and hematological parameters. The experiments were conducted in male rats of the Wistar line, weighing 200-220 g, of which four groups of animals were formed: 1) A control group - they injected drinking water through a metal probe in a volume equivalent to the volume of an aqueous solution of $\mathrm{Cd}^{2+}$ salts and $\mathrm{Pb}^{2+} ; 2$ ) Experimental group 1 - animals were administered a $0.029 \%$ aqueous solution of cadmium chloride at a dose of $4.0 \mathrm{mg} \mathrm{kg}^{-1}$; 3) Experimental group 2 - animals were administered $16.6 \%$ aqueous lead acetate solution at a dose of $200 \mathrm{mg} \mathrm{kg}$; 4) Experimental group 3 - animals were administered $16.6 \%$ aqueous lead acetate solution at a dose of $100 \mathrm{mg} \mathrm{kg}$ and $0.029 \%$ aqueous cadmium chloride solution at a dose of $2.0 \mathrm{mg} \mathrm{kg}$. Throughout the experiment, rats were kept in a balanced diet containing all the necessary components, and animals were given drinking water, without restriction, from 0.2 liter glass bowls. On the basis of the conducted researches it is established that at loading of an organism of rats by cadmium and Lead salts in rats the weight gain in comparison with intact animals decreased. Reduction of live weight gain in rats by heavy metal intoxication was accompanied by hypo- and hypertrophy of the internal organs. These changes are related to the cumulative and sorption capacity of these metal ions, which contribute to the development of endogenous intoxication of rats in the experimental groups. Chronic lead-cadmium toxicosis in rats was accompanied by erythrocytopenia and leukopenia, as well as a decrease in hemoglobin with a simultaneous increase in erythrocyte volume and average erythrocyte hemoglobin content.
\end{abstract}

Key words: Toxicology; Heavy metals; Cadmium; Lead; Blood; Organ weights

\section{Introduction}

Modern functioning of the economy is accompanied by an increase in technogenic load. Anthropogenic activity contributes to the dispersion of a large number of chemical elements involved in the migration process. Heavy metal salts, particularly Cadmium and Lead, which are highly toxic and can affect living organisms, even at low concentrations, are among the leading chemical pollutants (Ali et al., 1986; Myslyva, 2013; Hutyi, 2015; Gutyj et al., 2018; 2019). The frequency and severity of ecologically dependent diseases resulting from anthropogenic pollution of the biosphere indicates the relevance of this problem (Gutyj et al., 2016; Grynevych et al., 2018; Slivinska et al., 2019).

Heavy metals are priority pollutants of atmospheric air, reservoir water and soil globally and regionally. Due to their high migratory capacity, tendency to bioaccumulation and polytropicity, metals pose a risk to humans not only by direct action but also by adversely affecting the hygienic performance of environmental objects (Khariv et al., 2016; Hariv \& Gutyj, 2016; Vishchur et al., 2016; Kozak \& Brygadyrenko, 2018; Vishchur et al., 2019; Komlyk \& Brygadyrenko, 2019; Avtaeva et al., 2019). A mixture of toxic substances that can act on living organisms both independently of one another and interact, can affect the degree of toxic effect of individual substances. Thus, in case of environmental pollution by heavy metals it is proved that the manifestations of toxic action may depend on the interaction between them, which leads to change of thresholds, and therefore not only the toxicity of each component of the system but also their combined action is important (Slobodian et al., 2019).

The results of many experimental studies indicate that Cadmium and Lead have a toxic effect on a number of organs and systems in mammals (Marushko et al., 2010; Petrynych et al., 2017; Ostapyuk \& Gutyj, 2018; 2019). Lead and Cadmium, when introduced into the body of animals, easily connect to thiol groups of apoproteins, and thus change the activity of antioxidant, microsomal and other enzymatic systems, affect the exchange of macro- and microelements, exhibit carcinogenic action (Al-Azemi et al., 2010; Stepanchuk, 2014; Lavryshyn et al., 2018; 2019; Sobolev et al., 2019).

The aim of the study was to determine the effect of Cadmium and Lead salts on body weight gain and rat body weights and hematological parameters.

\section{Material and Methods}

The experiments were conducted on male rats of the Wistar line, weighing 200-220 g, from which 4 groups of animals were formed:

1 - Control group - injected drinking water through a metal probe in a volume equivalent to the volume of aqueous solution of salts $\mathrm{Cd}^{2+}$ and $\mathrm{Pb}^{2+} ; 2$ - Experimental group 1 - Animals were administered a $0.029 \%$ aqueous solution of cadmium chloride at a dose of $4.0 \mathrm{mg} \mathrm{kg}^{-1} ; 3$ - Experimental group 2 - Animals were administered $16.6 \%$ aqueous lead acetate solution at a dose of $200 \mathrm{mg} \mathrm{kg}^{-1}$; 
4 - Experimental group 3 - Animals were administered $16.6 \%$ aqueous solution of lead acetate at a dose of $100 \mathrm{mg} \mathrm{kg}^{-1}$ and $0.029 \%$ aqueous solution of cadmium chloride at a dose of $2.0 \mathrm{mg} \mathrm{kg}^{-1}$.

Throughout the experiment, rats were kept in an equilibrium diet balanced with all the necessary components, and animals were provided with drinking water without restrictions from 0.2 liter glass bowls.

All animal manipulations were carried out in accordance with the European Convention for the Protection of Vertebrate Animals, which is used for experimental and scientific purposes (Strasbourg, 1986).

Blood for biochemical studies was collected under ether anesthesia from the jugular vein on days 1, 7, 14, 21, and 28 of the experiment. Leukocyte counts in the blood were counted using a Tiurk reagent on the grid of Goryaev's counting chamber under a microscope with an 8x lens, 10x eyepiece (Vlizlo, 2012).

The number of erythrocytes was determined by photocolorimetric registration of the optical density of the test samples on CPK-3 at a wavelength of $670 \mathrm{~nm}$. The concentration of hemoglobin was investigated by hemoglobincyanide method followed by photocolorimetry at the optical path length of $540 \mathrm{~nm}$. The hematocrit value was determined by a micromethod in the modification of J. Todorov, by centrifugation of capillary tubes in a MCG-8 microcentrifuge with the detection of results using a scale. Red blood indices: mean erythrocyte volume (ESR), hemoglobin content in erythrocyte (VGE), mean hemoglobin concentration in erythrocyte (SCGE), color index (KP) were calculated using formulas (Vlizlo, 2012).

All animal manipulations were performed according to the Calculation of Organ Weight Ratios (Kotsiumbas et al., 2006; Gutyj et al., 2016; Gutyj et al., 2017). Having obtained absolute mass of organs, we determined the weight coefficients by the formula:

$$
\mathrm{K}=\mathrm{m}_{1} / \mathrm{m}_{2}
$$

where $\mathrm{m}_{1}$ is the mass of the organ, $\mathrm{g} ; \mathrm{m}_{2}$ - body weight of the animal, $\mathrm{kg}$.

Analysis of the research results was performed using the Statistica 6.0 software package. The likelihood of differences was evaluated by Student's t-test. The results were considered significant at $P \leq 0.05$. Data in the Tables $1-3$ presented as mean value and standard deviation.

\section{Results and Discussion}

As a result of the studies in the experimental groups of animals that were intoxicated with heavy metals, there was a tendency to reduce the weight gain of rats (Figure 1 ).

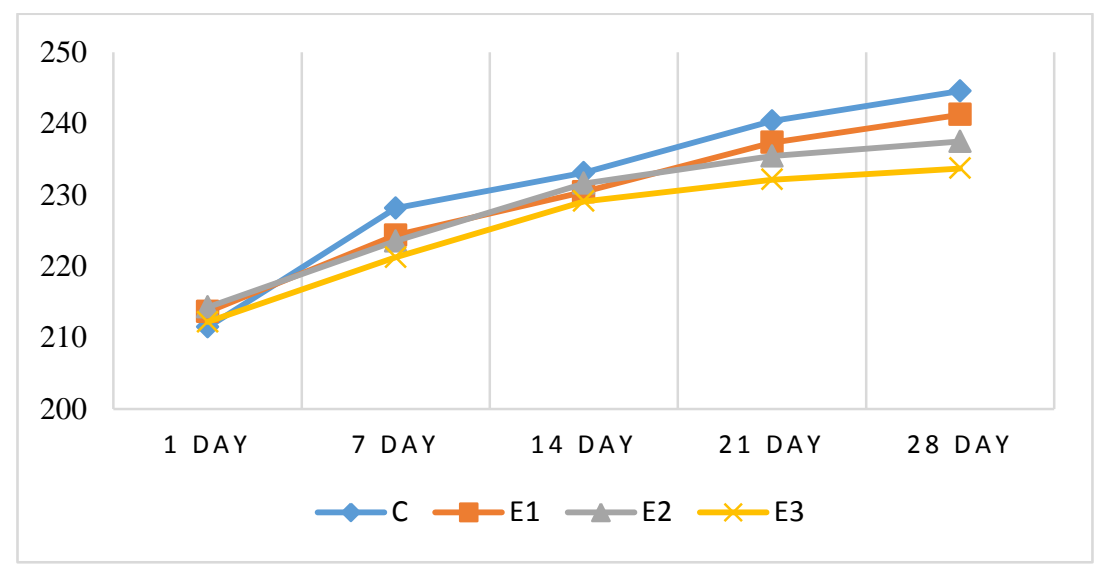

Figure 1. Weight gain in rats by heavy metal intoxication; 1 - control group (C); 2 - the group struck by Cadmium (E1); 3 - lead struck group (E2); 4 - the group struck by Cadmium and Lead (E3).

It should be noted that at the beginning of the experiment, the body weight of rats in the control and experimental groups ranged from $211.44 \pm 5.9,213.60 \pm 5.7,214.25 \pm 6.6$, and $213,17+5,2 \mathrm{~g}$. In the rats of the experimental groups, which were loaded with heavy metals, it should be noted that the weight loss in the second and third experimental groups for the 28th day of the experiment, where compared with the control group rats it decreased by 2.5 and $4.1 \%$, respectively.

The rats mass of the first experimental group was slightly higher, where it was $240.22 \pm 5.4 \mathrm{~g}$, respectively.

The average daily weight gain of rats was highest in the first experimental group, slightly lower in the second experimental group and lowest in the third experimental group. The total weight gain of rats for 28 days was $159 \mathrm{~g}$ in the first experimental group, 132 $\mathrm{g}$ in the second and $117 \mathrm{~g}$ in the third. Reduction of live weight gain in rats by heavy metal intoxication was accompanied by hypoand hypertrophy of the internal organs, which are characterized by different metabolic intensities (Table 2).

In the animals of the first experimental group to which the cadmium load was carried out, there was a tendency to increase the lung weight factor by $2.8 \%$, the liver - by $7.6 \%$, and the brain - by $18.7 \%$ relative to the rats in the control group. Also in this study group was found a decrease in heart weight by $8.7 \%$, kidney - by $2.0 \%$, spleen - by $2.0 \%$ relative to the control group of animals.

In the rats of the second experimental group, which was injected with a $16.6 \%$ aqueous solution of lead acetate at a dose of 200 $\mathrm{mg} / \mathrm{kg}$, increased heart weight by $2.6 \%$, lungs - by $4.9 \%$, kidney - by $16.6 \%$, liver $-2.2 \%$, brain $-14.8 \%$ relative to rats in the control group. Also in this study group compared with the control was found a decrease in the weight ratio of the spleen by $4.4 \%$. Lead and Cadmium salts were introduced into the rats following the introduction of organs: the heart increased by $7.3 \%$, the kidney by $17.6 \%$, the liver by $9.4 \%$, and the brain by $21.1 \%$, then both lungs and spleen were $8.7 \%$ and $3.2 \%$ lower, respectively.

Thus obtained data of body weight gain and organ weights in rats by Cadmium and Lead intoxication are related to the cumulative and sorption capacity of these metal ions, which contribute to the development of endogenous intoxication of rats in the experimental groups. 
Table 1. Weight gain in rats by heavy metal intoxication, $g$ (here and further $n=6$ ).

\section{Body weight}

\section{At the beginning of the experiment \\ Group}

\begin{tabular}{cccc} 
& $\begin{array}{c}\text { Total by } \\
\text { group }\end{array}$ & $\begin{array}{c}\text { The average of } \\
\text { one animal }\end{array}$ & $\begin{array}{c}\text { Total by } \\
\text { group }\end{array}$ \\
C & 1269 & $211.44 \pm 5.9$ & 1455 \\
I & 1282 & $213.60 \pm 5.7$ & 1441 \\
II & 1286 & $214.25 \pm 6.6$ & 1418 \\
III & 1279 & $213.17 \pm 5.2$ & 1396 \\
\hline
\end{tabular}

\section{On the $28^{\text {th }}$ day of administration}

\section{Weight gain}

\begin{tabular}{ccc}
$\begin{array}{c}\text { Total } \\
\text { for } \mathbf{2 8} \\
\text { days } \\
\text { by } \\
\text { group }\end{array}$ & Daily average in terms of \\
& $\begin{array}{c}\text { all rats in } \\
\text { the group }\end{array}$ & $\begin{array}{c}\text { one rat } \\
\text { from the } \\
\text { group }\end{array}$ \\
186 & 6.64 & 1.107 \\
159 & 5.68 & 0.947 \\
132 & 4.71 & 0.785 \\
117 & 4.18 & 0.697 \\
\hline
\end{tabular}

Table 2. White rat internal mass ratios at day 28 after intragastric administration of lead and cadmium salts $(M \pm m, n=6)$.

\begin{tabular}{lcccc}
\hline Internal organs & $\mathbf{C}$ & $\mathbf{I}$ & Group & II \\
Heart & $3.43 \pm 0.137$ & $3.13 \pm 0.126$ & $3.52 \pm 0.162$ & $3.68 \pm 0.250$ \\
Lungs & $7.62 \pm 0.67$ & $7.83 \pm 0.82$ & $7.99 \pm 0.94$ & $6.96 \pm 0.301$ \\
Both kidneys & $6.46 \pm 0.062$ & $6.33 \pm 0.241$ & $7.53 \pm 0.322$ & $7.60 \pm 0.178$ \\
Right kidney & $3.22 \pm 0.038$ & $3.15 \pm 0.154$ & $3.80 \pm 0.173$ & $3.79 \pm 0.138$ \\
Left kidney & $3.24 \pm 0.041$ & $3.18 \pm 0.187$ & $3.73 \pm 0.165$ & $3.81 \pm 0.090$ \\
Spleen & $4.10 \pm 0.348$ & $4.02 \pm 0.127$ & $3.92 \pm 0.305$ & $3.97 \pm 0.231$ \\
Liver & $29.03 \pm 1.971$ & $31.25 \pm 0.673$ & $29.66 \pm 1.264$ & $31.75 \pm 0.744$ \\
Brain & $5.88 \pm 0.564$ & $6.98 \pm 0.392$ & $6.75 \pm 0.343$ & $7.12 \pm 0.410$ \\
\hline
\end{tabular}

In the study of hemoglobin in the blood of rats of the experimental groups was found to increase this indicator in the first experimental group by 17.4 and $6.2 \%$ relative to the control group. In the third study group, which used the salts of Cadmium and Lead, we observed a decrease in hemoglobin level to $95.4 \pm 0.67 \mathrm{~g} \mathrm{~L}^{-1}$, whereas in the control this indicator fluctuated within 112.3 $\pm 0.98 \mathrm{~g} \mathrm{~L}^{-1}$. This change in hemoglobin and erythrocyte counts in the blood of the first study group was accompanied by an increase in erythrocyte volume by $58.7 \%$ and an average erythrocyte hemoglobin content of $83.3 \%$.

In rats treated with Lead acetate at an appropriate dose, the average erythrocyte volume increased by $10.4 \%$, whereas in the third experimental group of rats administered the salts of Cadmium and Lead, this indicator increased by $61.5 \%$ relative to the control group of rats. The average content of hemoglobin in the erythrocyte was slightly higher in the second experimental group, where, respectively, was $18.2 \pm 0.75 \mathrm{PG}$, in the third experimental group this indicator was $21.6 \pm 1.42 \mathrm{PG}$, where compared to the control group it increased by $21.3 \%$ and $44.0 \%$.

The hematocrit in the first experimental group of rats was slightly higher than in the control group, whereas in the second and third experimental groups, on the contrary, the hematocrit was lower than the control parameters. Minor changes in hematocrit in the rats of the study groups are associated with an increase in erythrocyte volume.

It should be noted that administration to rats of cadmium chloride and lead acetate contributed to the lesion of the hematopoietic organs, as indicated by the low level of leukocytes in their blood. In particular, on the 28th day of the experiment, the number of leukocytes in the blood of the first experimental group was $6.19 \pm 1.10 \mathrm{G} / \mathrm{l}$, in the second experimental group - $6.76 \pm 0.62 \mathrm{G} / \mathrm{l}$, whereas in the control group it was $8.72 \pm 0.75 \mathrm{G} / \mathrm{l}$. The lowest leukocyte count was in the blood of rats of the third experimental group, which was carried out the aggregate setting of heavy metal salts.

In this group of animals, the leukocyte count was likely to decrease by $39.2 \%$ relative to controls. Thus, the results of the studies indicate that the loading of Cadmium and Lead leads to a change in the morphological composition of the blood of rats, which indicates a decrease in the number of erythrocytes, leukocytes, hemoglobin level with a simultaneous increase in the average erythrocyte volume and average content of erythrocyte.

In general, the established changes indicate a decrease in the oxygen capacity of the blood and disturbance of erythropoiesis under the influence of heavy metals. Such effects, if prolonged, may significantly impair the health and productivity of farm animals.

Our data are consistent with the results of studies by other authors on the negative impact of heavy metals on animals and humans. It was found that the total load of Cadmium and Lead salts, depending on the concentration level, duration of exposure and selected indicators of functional status assessment, the effect of both potentiation and summation, in addition, the effect of the combined effect changed in favor of summation.

The difficulty of predicting the nature of the combined action in each case, especially in the case of complex multicomponent combinations at the threshold and sub-threshold levels, is due to a number of reasons, including the peculiarity of biotransformation of exogenous chemicals in the body.

The mechanism of toxic exposure of heavy metals is associated with the blocking of sulfhydryl, carboxyl and amine groups of organic compounds. In the toxicodynamics of joint intoxication there is a violation of oxidation processes and activity of oxidoreductases, swelling and change of membrane permeability and disturbance of iron and copper. 
Table 3. Hematological parameters in rats on the 28th day of lead-cadmium load $(M \pm m, n=6)$.

\begin{tabular}{|c|c|c|c|c|}
\hline \multirow{2}{*}{ Indicators } & \multicolumn{4}{|c|}{ Group } \\
\hline & C & $\mathbf{I}$ & II & III \\
\hline Hemoglobin, $\mathrm{g} \mathrm{L}^{-1}$ & $112.3 \pm 0.98$ & $131.8 \pm 1.16$ & $119.3 \pm 0.18$ & $95.4 \pm 0.67$ \\
\hline Erythrocytes, $\mathrm{T} \mathrm{L}^{-1}$ & $7.48 \pm 0.08$ & $4.80 \pm 0.12$ & $6.54 \pm 0.13$ & $4.41 \pm 0.22$ \\
\hline Leukocytes, G L ${ }^{-1}$ & $8.72 \pm 0.75$ & $6.19 \pm 1.10$ & $6.76 \pm 0.62$ & $5.30 \pm 1.00$ \\
\hline Hematocrit, \% & $42.58 \pm 1.36$ & $43.35 \pm 1.01$ & $41.10 \pm 1.32$ & $40.55 \pm 0.50$ \\
\hline $\begin{array}{l}\text { The average erythrocyte } \\
\text { volume, } \mu \mathrm{m}^{3}\end{array}$ & $56.92 \pm 2.11$ & $90.31 \pm 1.90$ & $62.84 \pm 2.25$ & $91.95 \pm 1.40$ \\
\hline $\begin{array}{l}\text { The average content of } \\
\text { hemoglobin in red blood } \\
\text { cells, PG }\end{array}$ & $15.0 \pm 1.29$ & $27.5 \pm 2.57$ & $18.2 \pm 0.75$ & $21.6 \pm 1.42$ \\
\hline
\end{tabular}

\section{Conclusion}

At loading of an organism of rats by Cadmium and Lead salts in rats the weight gain in comparison with intact animals decreased. Reduction of live weight gain in rats by heavy metal intoxication was accompanied by hypo- and hypertrophy of the internal organs, characterized by different metabolic rates. These changes are related to the cumulative and sorption capacity of these metal ions, which contribute to the development of endogenous intoxication of rats in the experimental groups. Chronic lead-cadmium toxicosis in rats was accompanied by erythrocytopenia and leukopenia, as well as a decrease in hemoglobin with a simultaneous increase in erythrocyte volume and average erythrocyte hemoglobin content.

\section{References}

Al-Azemi, M., Omu, F. E., Kehinde, E. O., Anim, J. T., Oriowo, M. A., \& Omu, A. E. (2010). Lithium protects against toxic effects of cadmium in the rat testes. J. Assist. Reprod. Genet, 27(8), 469-476. doi: 10.1007/s10815-010-9426-3.

Ali, M. M., Murthy, R. C., \& Chandra, S. V. (1986). Developmental and longterm neurobehavioral toxicity of low-level in utero Cd exposure in rats. Neurobehavioral Toxicology and Teratology, 8(5), 463-468. https://www.ncbi.nlm.nih.gov/pubmed/ 3785508.

Avtaeva, T. A., Sukhodolskaya, R. A., Skripchinsky, A. V., \& Brygadyrenko, V. V. (2019). Range of Pterostichus oblongopunctatus (Coleoptera, Carabidae) in conditions of global climate change. Biosystems Diversity, 27(1), 76-84. doi: 10.15421/011912.

Grynevych, N., Sliusarenko, A., Dyman, T., Sliusarenko, S., Gutyj, B., Kukhtyn, M., Hunchak, V. Kushnir, V. (2018). Etiology and histopathological alterations in some body organs of juvenile rainbow trout Oncorhynchus mykiss (Walbaum, 1792) at nitrite poisoning. Ukrainian Journal of Ecology, 8(1), 402-408. doi: 10.15421/2018_228

Gutyi, B., Ostapiuk, A., Kachmar, N., Stadnytska, O., Sobolev, O., Binkevych, V., Petryshak, R., Petryshak, O., Kulyaba, O., Naumyuk, A., Nedashkivsky, V., Nedashkivska, N., Magrelo, N., Golodyuk, I., Nazaruk, N., \& Binkevych, O. (2019). The effect of cadmium loading on protein synthesis function and functional state of laying hens' liver. Ukrainian Journal of Ecology, 9(3), 222226.

Gutyj, B. V., Gufriy, D. F., Binkevych, V. Y., Vasiv, R. O., Demus, N. V., Leskiv, K. Y., Binkevych, O. M., \& Pavliv, O. V. (2018). Influence of cadmium loading on glutathione system of antioxidant protection of the bullocks'bodies. Scientific Messenger of Lviv National University of Veterinary Medicine and Biotechnologies, 20(92), 34-40. doi: 10.32718/nvlvet9207.

Gutyj, B., Grymak, Y., Drach, M., Bilyk, O., Matsjuk, O., Magrelo, N., Zmiya, M., \& Katsaraba, O. (2017). The impact of endogenous intoxication on biochemical indicators of blood of pregnant cows. Regulatory Mechanisms in Biosystems, 8(3), 438-443. doi: $10.15421 / 021768$.

Gutyj, B., Khariv, I., Binkevych, V., Binkevych, O., Levkivska, N., Levkivskyj, D., \& Vavrysevich, Y. (2017). Research on acute and chronic toxity of the experimental drug Amprolinsyl. Regulatory Mechanisms in Biosystems, 8(1), 41-45. doi: 10.15421/021708.

Gutyj, B., Martyshchuk, T., Bushueva, I., Semeniv, B., Parchenko, V., Kaplaushenko, A., Magrelo, N., Hirkovyy, A., Musiy, L., \& Murska, S. (2017). Morphological and biochemical indicators of blood of rats poisoned by carbon tetrachloride and subject to action of liposomal preparation. Regulatory Mechanisms in Biosystems, 8(2), 304-309. doi: 10.15421/021748.

Gutyj, B., Nazaruk, N., Levkivska, A., Shcherbatyj, A., Sobolev, A., Vavrysevych, J., Hachak, Y., Bilyk, O., Vishchur, V., \& Guta, Z. (2017). The influence of nitrate and cadmium load on protein and nitric metabolism in young cattle. Ukrainian Journal of Ecology, $7(2), 9-13$

Gutyj, B., Paska, M., Levkivska, N., Pelenyo, R., Nazaruk, N., \& Guta, Z. (2016). Study of acute and chronic toxicity of 'injectable mevesel' investigational drug. Biological Bulletin of Bogdan Chmelnitskiy Melitopol State Pedagogical University, 6(2), $174-180$.

Gutyj, B., Stybel, V., Darmohray, L., Lavryshyn, Y., Turko, I., Hachak, Y., Shcherbatyy, A., Bushueva, I., Parchenko, V., Kaplaushenko, A., \& Krushelnytska, O. (2017). Prooxidant-antioxidant balance in the organism of bulls (young cattle) after using cadmium load. Ukrainian Journal of Ecology, 7(4), 589-596.

Gutyj, B.V., Murs'ka, S.D., Gufrij, D.F., Hariv, I.I., Levkivs'ka, N.D., Nazaruk, N.V., Gajdjuk, M.B., Pryjma, O.B., Bilyk, O.Ja., \& Guta, Z.A. (2016). Influence of cadmium loading on the state of the antioxidant system in the organism of bulls. Visnyk of Dnipropetrovsk University. Biology, ecology, 24(1), 96-102. doi:10.15421/011611

Gutyj, B.V., Ostapyuk, A.Y., Sobolev, O.I., Vishchur, V.J., Gubash, O.P., Kurtyak, B.M, Kovalskyi, Y.V., Darmohray, L.M., Hunchak, A.V., Tsisaryk, O.Y., Shcherbatyy, A.R., Farionik, T.V., Savchuk, L.B., Palyadichuk, O.R., \& Hrymak, K. (2019). Cadmium burden impact on morphological and biochemical blood indicators of poultry. Ukrainian Journal of Ecology, 9(1), 236-239

Hariv, M.I., \& Gutyj, B.V. (2016). Vplyv liposomalnoho preparatu Butaintervit na proteinsyntezuvalnu funktsiiu pechinky shchuriv za otruiennia tetrakhlormetanom [Influence of the liposomal preparation Butaintervite on protein synthesis function in the livers of rats under the influence of carbon tetrachloride poisoning]. Visnyk of Dnipropetrovsk University. Biology, medicine, 7(2), 123-126. doi: $10.15421 / 021622$ (in Ukrainian). 
Hutyi, B. V. (2015). Aktyvnist systemy antyoksydantnoho zakhystu orhanizmu bychkiv za hostroho kadmiievoho toksykozu. Naukovyi visnyk Lvivskoho natsionalnoho universytetu veterynarnoi medytsyny ta biotekhnolohii im. Gzhytskoho, 17, 1(1), 31-36. Rezhym dostupu: http://nbuv.gov.ua/UJRN/nvlnu_2015_17_1(1)_8 (in Ukrainian).

Khariv, M., Gutyj, B., Butsyak, V., \& Khariv, I. (2016). Hematological indices of rat organisms under conditions of oxidative stress and liposomal preparation action. Biological Bulletin of Bogdan Chmelnitskiy Melitopol State Pedagogical University. 6 (1), $276-289$. doi: $10.15421 / 201615$.

Komlyk, V. O., \& Brygadyrenko, V. V. (2019). Morphological variability of Bembidion minimum (Coleoptera, Carabidae) populations under the influence of natural and anthropogenic factors. Biosystems Diversity, 27(3), 250-269. doi: 10.15421/011935.

Kotsiumbas, I.Ia., Malyk, O.H., \& Patereha, I.P. (2006). Doklinichni doslidzhennia veterynarnykh likarskykh zasobiv. L.: Triada plius (in Ukrainian).

Kozak, V. M., \& Brygadyrenko, V. V. (2018). Impact of cadmium and lead on Megaphyllum kievense (Diplopoda, Julidae) in a laboratory experiment. Biosystems Diversity, 26(2), 128-131. doi: 10.15421/011820.

Lavryshyn, Y. Y., Gutyj, B. V., Palyadichuk, O. R., \& Vishchur, V. Y. (2018). Morphological blood indices of bulls in experimental chronic cadmium toxicosis. Scientific Messenger of Lviv National University of Veterinary Medicine and Biotechnologies, 20(88), 108114. doi: 10.32718/nvlvet8820.

Lavryshyn, Y. Y., Gutyj, B. V., Paziuk, I. S., Levkivska, N. D., Romanovych, M. S., Drach, M. P., \& Lisnyak, O. I. (2019). The effect of cadmium loading on the activity of the enzyme link of the glutathione system of bull organism. Scientific Messenger of Lviv National University of Veterinary Medicine and Biotechnologies. Series: Veterinary sciences, 21(95), 107-111. doi: 10.32718/nvlvet9520.

Marushko, Yu.V., Tarynska, O.L., Olefir, T.I., \& Fus, S.V. (2010). Kadmii: Nakopychennia ta vplyv na orhanizm dytyny. Medychna nauka Ukrainy, 3, 62-67. Rezhym dostupu: http://nbuv.gov.ua/UJRN/nvnmu_2010_3_12 (in Ukrainian).

Myslyva, T. M. (2013). Svynets i kadmii u hruntakh ahrolandshaftiv Zhytomyrskoho Polissia. Visnyk Sumskoho natsionalnoho ahrarnoho universytetu. Seriia: Ahronomiia i biolohiia, 3, 43-50. Rezhym dostupu: http://nbuv.gov.ua/UJRN/Vsna_agro_2013 _3_13 (in Ukrainian).

Myslyva, T. M. (2013). Svynets i kadmii u hruntakh pryrodnykh i ahrolandshaftiv Zhytomyrskoho Polissia. Visnyk Zhytomyrskoho natsionalnoho ahroekolohichnoho universytetu, 1(1), 36-49. Rezhym dostupu: http://nbuv.gov.ua/UJRN/Vzhnau_2013_1(1)_8 (in Ukrainian).

Ostapyuk, A. Y., \& Gutyj, B. V. (2018). Influence of cadmium loading on morphological parameters of blood of the Laying Hens. Scientific Messenger of Lviv National University of Veterinary Medicine and Biotechnologies, 20(88), 48-52. doi: $10.32718 /$ nvlvet8808.

Ostapyuk, A. Y., \& Gutyj, B. V. (2019). Influence of cadmium sulfate at different doses on the functional state of the liver of laying chicken. Scientific Messenger of Lviv National University of Veterinary Medicine and Biotechnologies. Series: Veterinary sciences, 21(94), 103-108. doi: 10.32718/nvlvet9419.

Petrynych, V. V., Vlasyk, L. I., \& Petrynych, O. A. (2017). Svynets: toksykolohichni, hihiienichni ta biolohichni aspekty. Klinichna ta eksperymentalna patolohiia, 16(2), 97-102. Rezhym dostupu: http://nbuv.gov.ua/UJRN/kep_2017_16_2_22 (in Ukrainian).

Slivinska, L.G., Shcherbatyy, A.R., Lukashchuk, B.O., Zinko, H.O., Gutyj, B.V., Lychuk, M.G., Chernushkin, B.O., Leno, M.I., Prystupa, O.I., Leskiv, K.Y., Slepokura, O.I., Sobolev, O.I., Shkromada, O.I., Kysterna, O.S., Musiienko, O.V. (2019). Correction of indicators of erythrocytopoesis and microelement blood levels in cows under conditions of technogenic pollution. Ukrainian Journal of Ecology, 9(2), 127-135

Slobodian, S. O., Gutyj, B. V., \& Leskiv, K. Y. (2019). The level of lipid peroxidation products in the rats blood under prolonged cadmium and lead loading. Ukrainian Journal of Veterinary and Agricultural Sciences, 2(3), 15-18. doi: 10.32718/ujvas2-3.04

Sobolev O.I. et al. (2019). Chemical composition, energy and biological value of broiler chicken meat caused by various doses of selenium. Ukrainian Journal of Ecology, 9(4), 622-627

Sobolev, O.I., Gutyj, B.V., Darmohray, L.M., Sobolieva, S.V., Ivanina, V.V., Kuzmenko, O.A., Karkach, P.M., Fesenko, V.F., Bilkevych, V.V., Mashkin, Y.O., Trofymchuk, A.M., Stavetska, R.V., Tkachenko, S.V., Babenko, O.I., Klopenko, N.I., Chernyuk, S.V. (2019). Lithium in the natural environment and its migration in the trophic chain. Ukrainian Journal of Ecology, 9(2), 195-203

Sobolev, O.I., Gutyj, B.V., Sobolieva, S.V., Fesenko, V.F., Bilkevych, V.V., Babenko, O.I., Klopenko, N.I., Kachan, A.D., Kosior, L.T., Lastovska, I.O., Vered, P.I., Shulko, O.P., Onyshchenko, L.S., Slobodeniuk, O.I. (2019). The influence of different doses of lithium additive in mixed feed on the balance of nitrogen in organism of goslings. Ukrainian Journal of Ecology, 9(2), 91-96.

Sobolev, O.I., Gutyj, B.V., Sobolieva, S.V., Shaposhnik, V.M., Sljusarenko, A.A., Stoyanovskyy, V.G., Kamratska, O.I., Karkach, P.M., Bilkevych, V.V., Stavetska, R.V., Babenko, O.I., Bushtruk, M.V., Starostenko, I.S., Klopenko, N.I., Korol'-Bezpala, L.P., Bezpalyi, I.F. (2019) Digestibility of nutrients by young geese for use of lithium in the composition of fodder. Ukrainian Journal of Ecology, 9(1),

1-6.

Stepanchuk, V. V. (2014). Ontohenetychni osoblyvosti tsyrkadiannykh khronorytmiv vilnoradykalnoho homeostazu za umov svyntsevoho otruiennia. Klinichna ta eksperymentalna patolohiia, 13(2), 131-133. Rezhym dostupu: http://nbuv.gov.ua/UJRN/kep_2014_13_2_33 (in Ukrainian).

Vishchur, V. Y. Saranchuk, I. I., \& Gutyj, B. V. (2016). Fatty acid content of honeycombs depending on the level of technogenic loading on the environment. Visnyk of Dnipropetrovsk University. Biology, Ecology, 24(1), 182-187. doi: 10.15421/011622

Vishchur, V. Y., Gutyj, B. V., Nischemenko, N. P., Kushnir, I. M., Salata, V. Z., Tarasenko, L. O., Khimych, M. S., Kushnir, V. I., Kalyn, B. M., Magrelo, N. V., Boiko, P. K., Kolotnytskyy, V. A., Velesyk, T., Pundyak, T. O., \& Gubash, O. P. (2019). Effect of industry on the content of fatty acids in the tissues of the honey-bee head. Ukrainian Journal of Ecology, 9(3), 174-179. doi: 10.15421/2019_727.

\section{Citation:}

Lopotych, N., Panas, N., Datsko, T., Slobodian, S. (2020). Influence of heavy metals on hematologic parameters, body weight gain and organ weight in rats. Ukrainian Journal of Ecology, 10(1), 175-179.

(cc) $\mathrm{EY}$ This work is licensed under a Creative Commons Attribution 4.0. License 